\title{
The effect of homozygous deletion of the BBOX1 and Fibin genes on carnitine level and acyl carnitine profile
}

\author{
Ali Rashidi-Nezhad ${ }^{1,2,3}$, Saeed Talebi ${ }^{2}$, Homeira Saebnouri ${ }^{2}$, Seyed Mohammad Akrami2 ${ }^{2 *}$ and Alexandre Reymond ${ }^{1 *}$
}

\begin{abstract}
Background: Carnitine is a key molecule in energy metabolism that helps transport activated fatty acids into the mitochondria. Its homeostasis is achieved through oral intake, renal reabsorption and de novo biosynthesis. Unlike dietary intake and renal reabsorption, the importance of de novo biosynthesis pathway in carnitine homeostasis remains unclear, due to lack of animal models and description of a single patient defective in this pathway.

Case presentation: We identified by array comparative genomic hybridization a 42 months-old girl homozygote for a $221 \mathrm{~Kb}$ interstitial deletions at 11p14.2, that overlaps the genes encoding Fibin and butyrobetaine-gamma 2-oxoglutarate dioxygenase 1 (BBOX1), an enzyme essential for the biosynthesis of carnitine de novo. She presented microcephaly, speech delay, growth retardation and minor facial anomalies. The levels of almost all evaluated metabolites were normal. Her serum level of free carnitine was at the lower limit of the reference range, while her acylcarnitine to free carnitine ratio was normal.

Conclusions: We present an individual with a completely defective carnitine de novo biosynthesis. This condition results in mildly decreased free carnitine level, but not in clinical manifestations characteristic of carnitine deficiency disorders, suggesting that dietary carnitine intake and renal reabsorption are sufficient to carnitine homeostasis. Our results also demonstrate that haploinsufficiency of BBOX1 and/or Fibin is not associated with Primrose syndrome as previously suggested.
\end{abstract}

Keywords: Carnitine, BBOX1, Fibin, CNV, Primrose syndrome

\section{Background}

Carnitine (L-3-hydroxy-4-N,N,N-trimethylaminobutyrate) is crucial for energy metabolism. It is a conditional essential nutrient found in animals, numerous microorganisms and plants [1-3]. It allows the transport of activated fatty acids from the cytosol to the mitochondria, where they are beta-oxidized. Other functions of carnitine include peroxisome fatty acid oxidation, modulating intracellular coenzyme A homeostasis and removal of excess acyl groups from the body via the preferential renal excretion of acylcarnitines [4-7].

\footnotetext{
* Correspondence: akramism@tums.ac.ir; Alexandre.reymond@unil.ch. ${ }^{2}$ Department of Medical Genetics, School of Medicine, Tehran University of Medical Sciences, Poursina St, P.O. Box: 14155-6447, Tehran, Iran 'Center for Integrative Genomics, University of Lausanne, 1015 Lausanne, Switzerland

Full list of author information is available at the end of the article
}

In mammals, carnitine homeostasis is achieved and maintained by a combination of absorption from dietary sources, de novo biosynthesis and efficient, renal tubular reabsorption $[4,8]$. Diet is the primary source of carnitine and dietary bioavailability of L-carnitine can vary considerably because of the broad range of nutritional choice. Meat, fish and dairy products are main sources in human, so vegetarians obtain very low amount of carnitine from their diet. However, compensatory mechanisms, including renal reabsorption in conjugation with de novo biosynthesis, are proficient in conserving carnitine homeostasis when dietary L-carnitine consumption is low $[4,8,9]$.

L-carnitine is synthesized from the amino acid precursors lysine and methionine via four enzymatic reactions. These enzymes are found in all the human cells, with the exception of butyrobetaine-gamma 2-oxoglutarate dioxygenase $1(\mathrm{BBOX} 1)$ that is only expressed in the liver, 
Table 1 Proband's anthropometric measurements

\begin{tabular}{lllll}
\hline Physical characteristics & Birth & Z-score & $\mathbf{4 2} \mathbf{~ m t h s}$ & Z-score \\
\hline Weight & $2.4 \mathrm{~kg}$ & -1.99 & $9.5 \mathrm{~kg}$ & -3.58 \\
Height & $44 \mathrm{~cm}$ & -2.76 & $80 \mathrm{~cm}$ & -4.85 \\
Head circumference & $29 \mathrm{~cm}$ & -4.12 & $37.5 \mathrm{~cm}$ & -8 \\
Body Mass Index (BMI) & 12.40 & -0.79 & 15.1 & -0.15 \\
\hline
\end{tabular}

kidneys and brain $[5,10]$. In contrast to the diet and renal reabsorption, the significance of carnitine de novo biosynthesis for energy homeostasis remains unclear [8], as no animal model and a single patient were described. While this patient was deficient for trimethyllysine hydroxylase epsilon (TMLHE), the first enzyme of the carnitine biosynthesis pathway $[11,12]$, we report on the first instance of homozygous deletion of BBOX1, the last enzyme of that pathway.

\section{Case presentation}

The proband girl was born at 38 weeks of gestation to a 23 years old mother after an uneventful pregnancy. According to birth measurements, she suffered from Intra uterine growth restriction (IUGR) with disproportionate congenital microcephaly (Table 1 ). The parents are firstdegree cousins. They have a second healthy child boy and did not experience any abortion or child death. Investigation of the family tree identified the spontaneous abortion of a first-degree cousin and a girl, $6^{\text {th }}$ degree proband's relative, presented hypotonia, mental retardation and facial dysmorphism. At 42 months, the proband presented a mild dysmorphic face with short forehead, high nasal bridge and flat nasal root, down slant pulpebral fissure, epicanthal folds, mild strabismus, long eye lashes, retrognathia and large ears relative to her face (Figure 1A-B). Her anthropometric measurements showed growth retardation (Table 1). She was hyperactive with a history of drooling and several attacks of unprovoked seizures that are now under control without antiepileptic drug. Her neurological examination showed a mild generalized hypertonia with mild contracture in knees but her balance, motor, sensory and reflexes were all in the normal ranges. The proband, has a history of motor delay and spasticity in lower limbs, which was improved with physical therapy. On the contrary her speech delay showed no improvement upon therapy. The proband social and cognition axes of development were almost normal. The auditory brainstem response (ABR) was also normal. However, the brain magnetic resonance imaging (MRI) showed severe microcephaly and small frontal lobes with no evidence of gross structural abnormality.

The proband's karyotype at a resolution of about 350 bands was normal. NimblegenHuman CGH $3 \times 720 \mathrm{~K}$ Whole-Genome Tiling v3.1 Array analysis [13] of her genomic DNA showed a $241 \mathrm{~Kb}$ interstitial homozygous deletion at 11p14.2 (Figure 2A-B). The complete genotype of the proband is therefore arr 11p14.2 (26,954,789$27,196,089) \times 0$. We used QPCR as previously described [14] to confirm this rearrangement in the proband and to show that both parents are heterozygous for the deletion (Figure 2B-C). This region encompasses Fibin (Fin Bud Initiation Factor Homolog) and BBOX1 (butyrobetaine-gamma 2-oxoglutarate dioxygenase 1) (Figure 2B), a TGF-beta dependent gene that encodes a secreted protein essential for pectoral fin bud initiation in zebrafish $[15,16]$ and an essential component of de novo carnitine biosynthesis $[5,10]$, respectively. A similar almost fully overlapping heterozygous $225 \mathrm{~kb}$ deletion (Figure 2B) was suggested to be the cause of Primrose syndrome (OMIM\#259050) at the heterozygote state [17]. The absence of ossified ear cartilage and muscle wasting specific to this pathology in the proband and both her parents, who are homo- and heterozygote for this rearrangement, respectively, goes against the implication of this deletion in this syndrome. Corroboratingly, some patients described in DECIPHER inherited similar deletions from their unaffected parents [18].
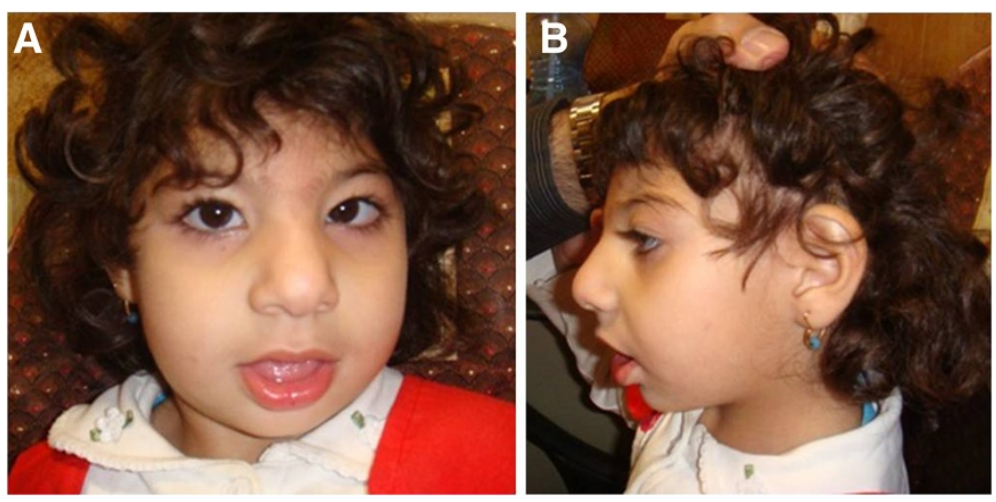

Figure 1 Proband's facial (A) and ear (B) appearance. 


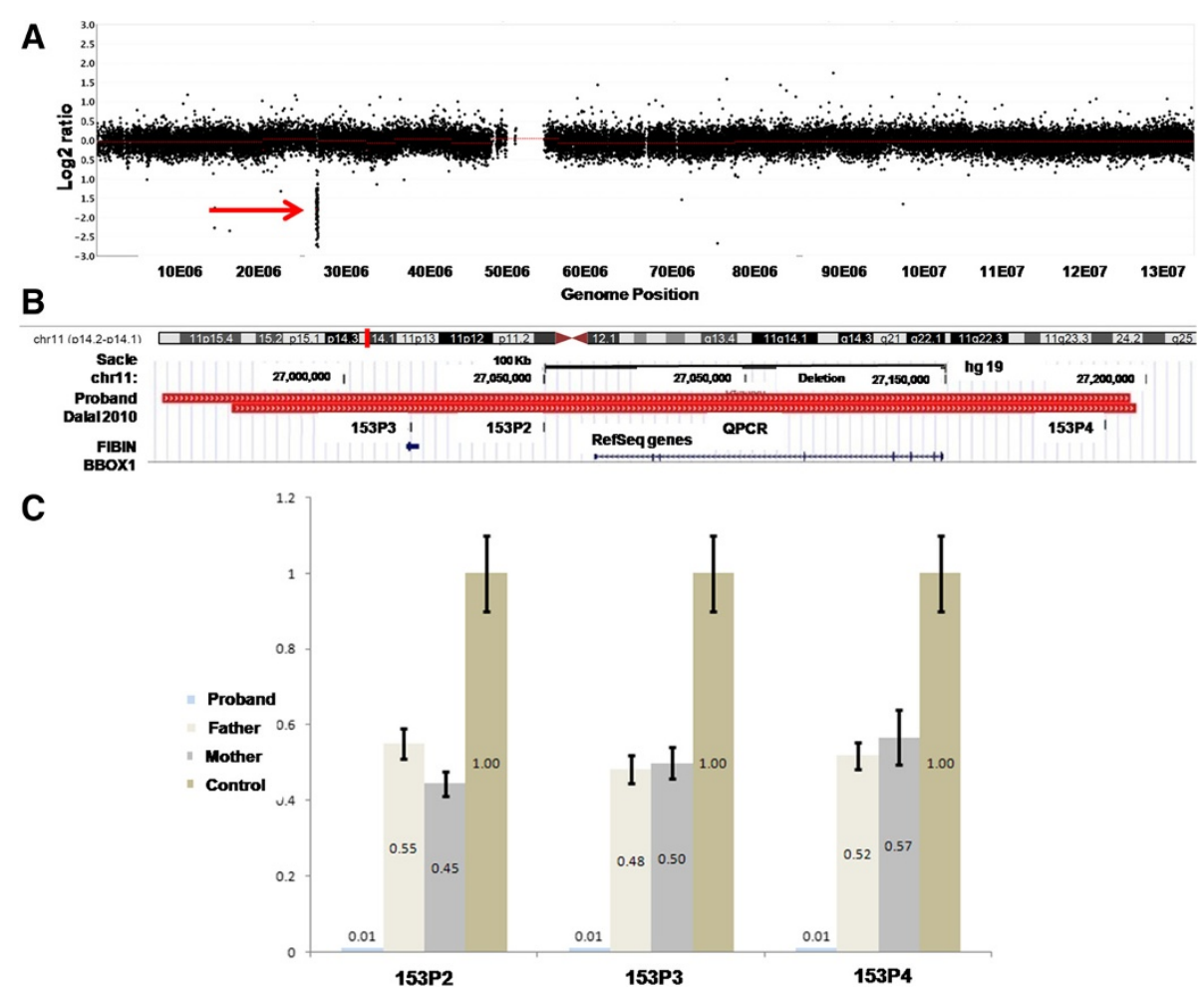

Figure 2 Proband's chromosome 11 genotype (A) NimblegenHuman CGH $3 \times 720$ K Whole-Genome Tiling array profile of proband's chromosomes 11. The homozygously deleted segment is pinpointed by a red arrow (B) Chromosomal position (top, marked by red box) and extents (bottom, red rectangles) of the homozygote deletion identified in the proband (top) and the heterozygote deletion described in a patient affected by Primrose syndrome [17] (bottom) in the UCSC genome browser. Both rearrangements encompass the Fibin and BBOX1 genes (GENCODE genes indicated in blue at the bottom of the panel [19]). The positions of the amplimers used to confirm the array CGH results are indicated by ticks (153P2-153P4). (C) Relative DNA amount was quantified by QPCR at human chromosome 11 loci defined in panel (B) for the proband, her mother and father, as well as an unaffected control. Data from three amplification reactions are represented as mean \pm S.D.

The proband's metabolic investigations were performed in dry blood spot using tandem mass spectrometry (MVZ wagnerstibbe für Laboratoriumsmedizin). The indices of common blood metabolites, electrolytes, liver function tests, creatine phosphokinase, lipid profile, blood gas and amino acid profiles were all in the normal range in particular that of acyl-carnitines and isovaleryl carnitine (Table 2). A detailed analysis of the different acylcarnitine levels at 42 and 60 months of age showed that all evaluated acylcarnitines were in reference ranges, whereas free carnitine (FC) $(25$ and $19 \mu \mathrm{mol} / \mathrm{L})$ was close to the normal lower limit $(20-70 \mu \mathrm{mol} / \mathrm{L})$ (Table 3). The proband's acylcarnitine $(15.5 \mu \mathrm{mol} / \mathrm{L}$ in proband, normal range $4-28 \mu \mathrm{mol} / \mathrm{L})$ to free carnitine $(\mathrm{AC} / \mathrm{FC})$ ratio was normal however (age-specific range 0.1-0.8) (Table 3).

\section{Discussion}

Carnitine is a critical molecule in the transport of fatty acids to the mitochondria and their subsequent betaoxidation. Its homeostasis is maintained through oral intake, renal reabsorption and de novo biosynthesis. Although, the importance of carnitine dietary intake and renal reabsorption were thoroughly studied [9,20-23], the impact of de novo biosynthesis remains unclear as we lack animal models and a single patient deficient in enzymes involved in the carnitine biosynthesis pathway was described $[8,11,12]$.

The female patient described here was referred to our genetic counseling and cytogenetic service because of microcephaly, dysmorphic features and IUGR. Array CGH revealed a homozygous deletion within chromosomal band 11p14.2 that deletes both the Fibin and the BBOX1 genes, probably resulting in absence of de novo carnitine biosynthesis. The evaluation of metabolites involved directly or indirectly in the fatty acid b-oxidation pathway showed an increased ratio of $\mathrm{AC} / \mathrm{FC}$ in the proband at 42 but not at 60 months of age (Table 3). Previous studies showed that such an increased ratio is an indicator of carnitine insufficiency; a situation in which there is inadequate free carnitine in response to an increase in metabolic needs [24-26]. It was further postulated that the $\mathrm{AC} / \mathrm{FC}$ ratio reflects the intramitochondrial acyl-CoA/ CoA ratio and thus that its alteration could be indicative of mitochondrial dysfunction [4]. The clinical and 
Table 2 Proband's metabolic investigations

\begin{tabular}{llll}
\hline FBS (P) & $98 \mathrm{mg} / \mathrm{dL}$ & Sodium (P) & $140 \mathrm{mEq} / \mathrm{L}$ \\
BUN (P) & $11 \mathrm{mg} / \mathrm{dL}$ & Potassium (P) & $3.8 \mathrm{mEq} / \mathrm{L}$ \\
Creatinine (P) & $0.6 \mathrm{mg} / \mathrm{dL}$ & Chloride (P) & $102 \mathrm{mEq} / \mathrm{L}$ \\
Cholesterol (P) & $164 \mathrm{mg} / \mathrm{dL}$ & $17-$ OH-Progesterone (DBS) & $<5 \mathrm{nmol} / \mathrm{L}$ \\
Triglyceride (P) & $63 \mathrm{mg} / \mathrm{dL}$ & TSH (DBS) & $<4 \mathrm{mU} / \mathrm{L}$ \\
HDL (P) & $49 \mathrm{mg} / \mathrm{dL}$ & Ketone (U) & Negative \\
LDL (P) & $102 \mathrm{mg} / \mathrm{dL}$ & Amino-acid TLC (U) & Normal pattern \\
SGOT (P) & $22 \mathrm{IU} / \mathrm{L}$ & Ferric Chloride Test (U) & Negative \\
SGPT (P) & $18 \mathrm{UU} / \mathrm{L}$ & DNPH Test (U) & Negative \\
CPK (P) & $167 \mathrm{IU} / \mathrm{L}$ & Na-Nitropruside Test (U) & Negative \\
Lactate (P) & $7.8 \mathrm{mg} / \mathrm{dL}$ & Amino-acids (DBS) (TMS) & unremarkable \\
Ammonia (B) & $44 \mathrm{mcg} / \mathrm{dL}$ & Acylcarnitines (DBS) (TMS)* & unremarkable* \\
Galactose (DBS) & $<18 \mathrm{mg} / \mathrm{dL}$ & Isovalerylcarnitine (DBS) & unremarkable \\
GALT (DBS) & $>20 \% \mathrm{act}$ & Glutaric acid (DBS) & unremarkable \\
PH (VBG) & 7.392 & Citrulline (DBS) & unremarkable \\
PCO2 (VBG) & $32.1 \mathrm{mmHg}$ & Arginosuccinate (DBS) & unremarkable \\
HCO3 (VBG) & $19 \mathrm{mmol} / \mathrm{L}$ & Succinylacetone (DBS) & $<5 \mu$ mol/L \\
BE (VBG) & $-3.4 \mathrm{mmol} / \mathrm{L}$ & Biotinidase (DBS) & $>40 \%$ act \\
\hline
\end{tabular}

*The detailed acylcarnitines results are further detailed in Table 3.

P: Plasma, B: Blood, U: Urine, FBS: Fasting Blood Sugar, BUN: Blood Urea Nitrogen, HDL: High Density Lipoprotein, LDL: Low Density Lipoprotein, SGOT: Serum Glutamic Oxaloacetic Transaminase, SGPT: Serum Glutamic Pyruvic Transaminase, CPK: Creatine Phosphokinase, GALT: Galactose-1-phosphate uridylyltransferase, VBG: venous Blood Gas, BE: Base Excess, TSH: Thyroid Stimulating Hormone, TLC: Thin Layer Chromatography, DNPH: Dinitrophenyl Hydrazine, DBS: Dry Blood Spot, TMS: Tandem Mass Spectroscopy.

metabolic findings in the proband are not compatible with the described carnitine deficiency disorders [27-32] even if her levels of free carnitine were close to the lower limit of normal range demonstrating that the hypothesis that a defect in carnitine biosynthesis will not manifest itself as a systemic carnitine deficiency in omnivorous humans [8]. Corroboratingly, the TMLHE-deficient patients showed normal plasma carnitine level [11,12].

It is unclear if the clinical features shown by the proband, such as microcephaly for example, are associated

Table 3 Proband's carnitine and acylcarnitine profile

\begin{tabular}{|c|c|c|c|c|c|}
\hline Acyl carnitine & Quantity ${ }^{1 s t}(\mu \mathrm{mol} / \mathrm{L})$ & Quantity $^{2 n d}(\mu \mathrm{mol} / \mathrm{L})$ & Acyl carnitine & Quantity $^{1 \text { st }}(\mu \mathrm{mol} / \mathrm{L})$ & Quantity $^{2 n d}(\mu \mathrm{mol} / \mathrm{L})$ \\
\hline $\mathrm{CO}(\mathrm{FC})$ & 25.00 & 19 & $\mathrm{C} 12$ & 0.13 & 0.17 \\
\hline$C 2$ & 15.30 & 6.5 & C12:1 & 0.04 & 0.12 \\
\hline C3 & 0.73 & 0.2 & C14 & 0.08 & 0.03 \\
\hline C3-DC & 0.04 & 0.04 & C14:1 & 0.05 & 0.03 \\
\hline C4 & 0.63 & 0.46 & C14:2 & 0.02 & 0.03 \\
\hline C4-DC & 1.10 & 0.41 & $\mathrm{C} 14-\mathrm{OH}$ & 0.01 & 0.02 \\
\hline C5 & 0.10 & 0.07 & $\mathrm{C} 16$ & 0.65 & 0.41 \\
\hline C5-DC & 0.06 & 0.04 & C16:1 & 0.06 & 0.03 \\
\hline $\mathrm{C} 5-\mathrm{OH}$ & 0.17 & 0.1 & $\mathrm{C} 16-\mathrm{OH}$ & 0.01 & 0.01 \\
\hline$C 5: 1$ & 0.06 & 0.04 & $\mathrm{C} 18$ & 0.42 & 0.26 \\
\hline C6 & 0.26 & 0.18 & C18:1 & 0.59 & 0.28 \\
\hline C6-DC & 0.00 & 0 & $\mathrm{C} 18: 1-\mathrm{OH}$ & 0.01 & 0.01 \\
\hline $\mathrm{C} 8$ & 0.10 & 0.07 & C18:2 & 0.16 & 0.07 \\
\hline $\mathrm{C} 10$ & 0.16 & 0.16 & $\mathrm{C} 18: 2-\mathrm{OH}$ & 0.01 & 0.01 \\
\hline C10:1 & 0.15 & 0.09 & $\mathrm{AC} / \mathrm{FC}$ & 0.84 & 0.52 \\
\hline
\end{tabular}

$1^{\text {st: }}$ Measurements were done after 12 hours fasting at 42 months of age.

$2^{\text {nd }}$ : Measurements were done after 12 hours fasting at 60 months of age. 
with her minor carnitine insufficiency. The etiology of the different observed phenotypes could be associated to the absence of the Fibin gene, the second gene encompassed within the 11p14.2 deletion. Fibin is a secreted protein identified in zebrafish, mice and humans potentially acting downstream of retinoic acid and wnt signaling. It is essential for pectoral fin bud initiation and $t b \times 5$ expression in zebrafish [16]. Alternatively they could be triggered by the reported perturbation of expression of copy-normal genes that neighbor structural rearrangement [33-37] or an unidentified recessive mutation inherited from both of her parents. Further studies are required to discriminate these different possibilities. Of note, consanguineous marriage is common practice and increasing in frequency in Iran [38,39]. It was suggested, however, that carnitine biosynthesis may be a risk factor for nondysmorphic autism as the TMLHE-deficient patient was identified in an autism spectrum disorder (ASD) cohort $[11,12]$. While our patient showed some dysmorphisms and global developmental delay she did not present autistic traits. Correspondingly she was microcephalic, a feature generally associated with schizophrenia rather than ASD that is generally associated with the mirroring macrocephaly [40-42].

\section{Conclusion}

In conclusion, we present to our knowledge, the first patient with homozygous deletion of $B B O X 1$, the second individual with a complete defect in carnitine de novo biosynthesis. She presents a mild decrease in free carnitine level but no clinical manifestations of carnitine deficiency disorders, suggesting that dietary carnitine intake and renal reabsorption are sufficient for carnitine homeostasis in omnivorous individuals.

\section{Consent}

All samples used in this study were collected with the approval of the local ethics committee ("Commission cantonale vaudoise d'éthique de la recherché sur l'être humain"). Written informed consent was obtained from the patient's parents for publication of this Case report and any accompanying images. A copy of the written consent is available for review by the Editor of this journal and appropriate informed consent. The latter signed by the parents includes the permission to publish pictures of the proband.

\section{Competing interests}

The authors declare no competing interests.

\section{Authors' contributions}

ARN, SMA and AR designed the study. ARN, ST and HS prepared the necessary materials and produced the data. ARN and AR wrote the manuscript. All authors read and approved the final manuscript.

\section{Acknowledgements}

We thank the patient and her parents for their participation and members of the Lausanne Genomic Technologies Facility for technical help. ARN is recipient of a scholarship from the Iran Ministry of Health. This work was supported by Iran National Science Foundation (INSF) (grant 87042100), Tehran University of Medical Sciences (TUMS) (grant 8999), Genetic Office of Iran Ministry of Health, and grants from the European Commission anEUploidy Integrated Project (037627), the Swiss National Science Foundation and a Swiss National Science Foundation Sinergia grant to AR. This study makes use of data generated by the DECIPHER Consortium. A full list of centres that contributed to the generation of the data is available from http://decipher.sanger.ac.uk and via email from decipher@sanger. ac.uk. Funding for the latter project was provided by the Wellcome Trust.

\section{Author details}

${ }^{1}$ Center for Integrative Genomics, University of Lausanne, 1015 Lausanne, Switzerland. ${ }^{2}$ Department of Medical Genetics, School of Medicine, Tehran University of Medical Sciences, Poursina St, P.O. Box: 14155-6447, Tehran, Iran. ${ }^{3}$ Maternal, Fetal and Neonatal Research Center, Tehran University of Medical Sciences, Tehran, Iran.

Received: 12 October 2013 Accepted: 26 June 2014

Published: 1 July 2014

\section{References}

1. Rebouche $\mathrm{CJ}$, Seim $\mathrm{H}$ : Carnitine metabolism and its regulation in microorganisms and mammals. Annu Rev Nutr 1998, 18:39-61.

2. Panter RA, Mudd JB: Carnitine levels in some higher plants. FEBS Lett 1969, 5(2):169-170.

3. Kleber HP: Bacterial carnitine metabolism. FEMS Microbiol Lett 1997, 147(1):1-9.

4. Reuter SE, Evans AM: Carnitine and acylcarnitines: pharmacokinetic, pharmacological and clinical aspects. Clin Pharmacokinet 2012, 51(9):553-572.

5. Bremer J: Carnitine-metabolism and functions. Physiol Rev 1983, 63(4):1420-1480.

6. Hoppel C: The role of carnitine in normal and altered fatty acid metabolism. Am J Kidney Dis 2003, 41(4 Suppl 4):S4-12.

7. Rebouche CJ, Paulson DJ: Carnitine metabolism and function in humans. Annu Rev Nutr 1986, 6:41-66.

8. Vaz FM, Wanders RJ: Carnitine biosynthesis in mammals. Biochem J 2002, 361(Pt 3):417-429.

9. Lombard KA, Olson AL, Nelson SE, Rebouche CJ: Carnitine status of lactoovovegetarians and strict vegetarian adults and children. Am J Clin Nutr 1989, 50(2):301-306.

10. Rebouche CJ, Engel AG: Tissue distribution of carnitine biosynthetic enzymes in man. Biochim Biophys Acta 1980, 630(1):22-29.

11. Celestino-Soper PB, Shaw CA, Sanders SJ, Li J, Murtha MT, Ercan-Sencicek AG, Davis L, Thomson S, Gambin T, Chinault AC, Ou Z, German JR, Milosavljevic A, Sutcliffe JS, Cook EH Jr, Stankiewicz P, State MW, Beaudet AL: Use of array CGH to detect exonic copy number variants throughout the genome in autism families detects a novel deletion in TMLHE. Hum Mol Genet 2011, 20(22):4360-4370.

12. Celestino-Soper PB, Violante S, Crawford EL, Luo R, Lionel AC, Delaby E, Cai G, Sadikovic B, Lee K, Lo C, Gao K, Person RE, Moss TJ, German JR, Huang N, Shinawi M, Treadwell-Deering D, Szatmari P, Roberts W, Fernandez B, Schroer RJ, Stevenson RE, Buxbaum JD, Betancur C, Scherer SW, Sanders SJ, Geschwind DH, Sutcliffe JS, Hurles ME, Wanders RJ, et al: A common $\mathrm{X}$-linked inborn error of carnitine biosynthesis may be a risk factor for nondysmorphic autism. Proc Natl Acad Sci U S A 2012, 109(21):7974-7981.

13. Rashidi-Nezhad A, Parvaneh N, Farzanfar F, Azimi C, Harewood L, Akrami SM, Reymond A: 2q34-qter duplication and 4q34.2-qter deletion in a patient with developmental delay. Eur J Med Genet 2012, 55(3):203-210.

14. Howald C, Merla G, Digilio MC, Amenta S, Lyle R, Deutsch S, Choudhury U, Bottani A, Antonarakis SE, Fryssira H, Dallapiccola B, Reymond A: Two high throughput technologies to detect segmental aneuploidies identify new Williams-Beuren syndrome patients with atypical deletions. J Med Genet 2006, 43(3):266-273.

15. Kosla J, Dvorak M, Cermak V: Molecular analysis of the TGF-beta controlled gene expression program in chicken embryo dermal myofibroblasts. Gene 2013, 513(1):90-100. 
16. Wakahara T, Kusu N, Yamauchi H, Kimura I, Konishi M, Miyake A, Itoh N: Fibin, a novel secreted lateral plate mesoderm signal, is essential for pectoral fin bud initiation in zebrafish. Dev Biol 2007, 303(2):527-535.

17. Dalal P, Leslie ND, Lindor NM, Gilbert DL, Espay AJ: Motor tics, stereotypies, and self-flagellation in primrose syndrome. Neurology 2010, 75(3):284-286

18. Firth HV, Richards SM, Bevan AP, Clayton S, Corpas M, Rajan D, Van Vooren S, Moreau Y, Pettett RM, Carter NP: DECIPHER: Database of Chromosomal Imbalance and Phenotype in Humans Using Ensembl Resources. Am J Hum Genet 2009, 84(4):524-533.

19. Harrow J, Frankish A, Gonzalez JM, Tapanari E, Diekhans M, Kokocinski F, Aken BL, Barrell D, Zadissa A, Searle S, Barnes I, Bignell A, Boychenko V, Hunt T, Kay M, Mukherjee G, Rajan J, Despacio-Reyes G, Saunders G, Steward C, Harte R, Lin M, Howald C, Tanzer A, Derrien T, Chrast J, Walters N, Balasubramanian S, Pei B, Tress M, et al: GENCODE: the reference human genome annotation for The ENCODE Project. Genome Res 2012, 22(9):1760-1774.

20. Krajcovicova-Kudlackova M, Simoncic R, Bederova A, Babinska K, Beder I: Correlation of carnitine levels to methionine and lysine intake. Physiol Res 2000, 49(3):399-402.

21. Treem WR, Stanley CA, Finegold DN, Hale DE, Coates PM: Primary carnitine deficiency due to a failure of carnitine transport in kidney, muscle, and fibroblasts. N Engl J Med 1988, 319(20):1331-1336.

22. Scholte HR, Rodrigues Pereira R, de Jonge PC, Luyt-Houwen IE, Hedwig M, Verduin M, Ross JD: Primary carnitine deficiency. J Clin Chem Clin Biochem Zeitschrift fur klinische Chemie und klinische Biochemie 1990, 28(5):351-357.

23. Stanley CA, DeLeeuw S, Coates PM, Vianey-Liaud C, Divry P, Bonnefont JP, Saudubray JM, Haymond M, Trefz FK, Breningstall GN, Wappner RS, Byrd DJ, Sansarcq C, Tein I, Grover W, Valle D, Rutledge SL, Treem WR: Chronic cardiomyopathy and weakness or acute coma in children with a defect in carnitine uptake. Ann Neurol 1991, 30(5):709-716.

24. Campos Y, Huertas R, Lorenzo G, Bautista J, Gutierrez E, Aparicio M, Alesso L, Arenas J: Plasma carnitine insufficiency and effectiveness of L-carnitine therapy in patients with mitochondrial myopathy. Muscle Nerve 1993, 16(2):150-153.

25. Bohles H, Evangeliou A, Bervoets K, Eckert I, Sewell A: Carnitine esters in metabolic disease. Eur J Pediatr 1994, 153(7 Suppl 1):S57-61.

26. Sayed-Ahmed MM, Aldelemy ML, Hafez MM, Al-Shabanah OA: Inhibition of gene expression of organic cation/carnitine transporter and antioxidant enzymes in oxazaphosphorines-induced acute cardiomyopathic rat models. Oxid Med Cell Longev 2012, 2012:452902.

27. Duran M: Disorders of Mitochondrial Fatty Acid Oxidation and Ketone Body Handling. In Physician's Guide to the Laboratory Diagnosis of Metabolic Diseases. Secondth edition. Berlin Heidelberg: Springer; 2003:309-334.

28. Korman SH, Waterham HR, Gutman A, Jakobs C, Wanders RJ: Novel metabolic and molecular findings in hepatic carnitine palmitoyltransferase I deficiency. Mol Genet Metab 2005, 86(3):337-343.

29. Yang BZ, Mallory JM, Roe DS, Brivet M, Strobel GD, Jones KM, Ding JH, Roe CR: Carnitine/acylcarnitine translocase deficiency (neonatal phenotype): successful prenatal and postmortem diagnosis associated with a novel mutation in a single family. Mol Genet Metab 2001, 73(1):64-70.

30. Bonnefont JP, Demaugre F, Prip-Buus C, Saudubray JM, Brivet M, Abadi N, Thuillier L: Carnitine palmitoyltransferase deficiencies. Mol Genet Metab 1999, 68(4):424-440.

31. van der Leij FR, Huijkman NC, Boomsma C, Kuipers JR, Bartelds B: Genomics of the human carnitine acyltransferase genes. Mol Genet Metab 2000, 71(1-2):139-153

32. Blau N, Duran M, Blaskovics ME, Gibson KM: Physician's Guide to the Laboratory Diagnosis of Metabolic Diseases. 2nd edition. Berlin Heidelberg New York: Springer; 2004

33. Chaignat E, Yahya-Graison EA, Henrichsen CN, Chrast J, Schutz F, Pradervand $\mathrm{S}$, Reymond A: Copy number variation modifies expression time courses. Genome Res 2011, 21(1):106-113.

34. Henrichsen $C N$, Chaignat E, Reymond A: Copy number variants, diseases and gene expression. Hum Mol Genet 2009, 18(R1):R1-8.

35. Henrichsen CN, Vinckenbosch N, Zollner S, Chaignat E, Pradervand S, Schutz F, Ruedi M, Kaessmann H, Reymond A: Segmental copy number variation shapes tissue transcriptomes. Nat Genet 2009, 41(4):424-429.

36. Reymond A, Henrichsen CN, Harewood L, Merla G: Side effects of genome structural changes. Curr Opin Genet Dev 2007, 17(5):381-386.
37. Merla G, Howald C, Henrichsen CN, Lyle R, Wyss C, Zabot MT, Antonarakis SE, Reymond A: Submicroscopic deletion in patients with Williams-Beuren syndrome influences expression levels of the nonhemizygous flanking genes. Am J Hum Genet 2006, 79(2):332-341.

38. Akrami SM, Osati Z: Is consanguineous marriage religiously encouraged? Islamic and Iranian considerations. J Biosoc Sci 2007, 39(2):313-316.

39. Akrami SM, Montazeri V, Shomali SR, Heshmat R, Larijani B: Is there a significant trend in prevalence of consanguineous marriage in Tehran? A review of three generations. J Genet Couns 2009, 18(1):82-86.

40. Jacquemont S, Reymond A, Zufferey F, Harewood L, Walters RG, Kutalik Z, Martinet D, Shen Y, Valsesia A, Beckmann ND, Thorleifsson G, Belfiore M, Bouquillon S, Campion D, de Leeuw N, de Vries BB, Esko T, Fernandez BA, Fernández-Aranda F, Fernández-Real JM, Gratacòs M, Guilmatre A, Hoyer J, Jarvelin MR, Kooy RF, Kurg A, Le Caignec C, Männik K, Platt OS, Sanlaville D, et al: Mirror extreme BMI phenotypes associated with gene dosage at the chromosome 16p11.2 locus. Nature 2011, 478(7367):97-102.

41. Shinawi M, Liu P, Kang SH, Shen J, Belmont JW, Scott DA, Probst FJ, Craigen WJ, Graham BH, Pursley A, Clark G, Lee J, Proud M, Stocco A, Rodriguez DL, Kozel BA, Sparagana S, Roeder ER, McGrew SG, Kurczynski TW, Allison L, Amato S, Savage S, Patel A, Stankiewicz P, Beaudet AL, Cheung SW, Lupski J: Recurrent reciprocal 16p11.2 rearrangements associated with global developmental delay, behavioural problems, dysmorphism, epilepsy, and abnormal head size. J Med Genet 2010, 47(5):332-341.

42. Zufferey F, Sherr EH, Beckmann ND, Hanson E, Maillard AM, Hippolyte L, Mace A, Ferrari C, Kutalik Z, Andrieux J, Aylward E, Barker M, Bernier R, Bouquillon S, Conus P, Delobel B, Faucett WA, GAylward E, Barker M, Bernier R, Bouquillon S, Conus P, Delobel B, Faucett WA, Goin-Kochel RP, Grant E, Harewood L, Hunter JV, Lebon S, Ledbetter DH, et al: A 600 kb deletion syndrome at $16 \mathrm{p} 11.2$ leads to energy imbalance and neuropsychiatric disorders. J Med Genet 2012, 49(10):660-668.

doi:10.1186/1471-2350-15-75

Cite this article as: Rashidi-Nezhad et al:: The effect of homozygous deletion of the BBOX1 and Fibin genes on carnitine level and acyl carnitine profile. BMC Medical Genetics 2014 15:75.

\section{Submit your next manuscript to BioMed Central and take full advantage of:}

- Convenient online submission

- Thorough peer review

- No space constraints or color figure charges

- Immediate publication on acceptance

- Inclusion in PubMed, CAS, Scopus and Google Scholar

- Research which is freely available for redistribution 